\title{
中国苔藓植物濒危等级的评估原则和评估结果
}

\author{
何强贾 渝 ${ }^{*}$ \\ (中国科学院植物研究所系统与进化植物学国家重点实验室, 北京 100093)
}

\begin{abstract}
摘要: 本文阐述了中国苔藓植物濒危等级的评估原则。这一原则主要参考“IUCN物种红色名录濒危等级和标准 (3.1版)”，同时也吸收了其他苔藓学家的评估指南和结果。作者将 10 年内发表的新分类群暂评为数据缺乏(DD)等 级, 根据馆藏标本份数估计栖息地物种成熟个体数。在此基础上, 对 3,221 个中国苔藓植物分类群进行评估, 结果 为: 极危(CR) 16种; 濒危(EN) 58 种; 易危(VU) 112种; 近危(NT) 214种; 无危(LC) 1,900种; 数据缺乏(DD) 921种。 极危、濒危和易危等级的受威胁苔藓植物合计 186 种，占中国苔藓植物种数的 $5.77 \%$ 。
\end{abstract}

关键词: IUCN红色名录; 受威胁类群; 评估; 苔蘚植物; 中国

\section{Assessing the threat status of China's bryophytes}

Qiang He, Yu Jia*

State Key Laboratory of Systematic and Evolutionary Botany, Institute of Botany, Chinese Academy of Sciences, Beijing 100093

\begin{abstract}
In this paper, the assessment principles of the endangered categories of Chinese bryophytes are expanded. This principle mainly refer to "IUCN Red List Categories and Criteria. Version 3.1", and also include results from other bryologists. The authors propose that those taxa published in the past ten years temporarily be classified as Data Deficient (DD), and estimate population sizes for all taxa be made based on herbarium specimens. A total of 3,221 taxa of Chinese bryophytes were evaluated based on the above principles and methods. Sixteen species were identified as Critically Endangered (CR), 58 species as Endangered (EN), 112 species as Vulnerable (VU), 214 species as Near Threatened (NT), 1,900 species as of Least Concern (LC), and 921 species are classified as Data Deficient (DD). Overall, 186 species of bryophytes (5.77\% of the bryophytes found in China) were identified as threatened (including CR, EN, and VU).
\end{abstract}

Key words: IUCN Red List; threatened taxa; assessment; bryophyte; China

世界自然保护联盟(IUCN)濒危物种红色名录 是根据《IUCN物种红色名录濒危等级和标准》 (IUCN Red List Categories and Criteria. Version 3.1) 评估得出, 它全面综合地评价了全球动植物物种保 护现状, 反映了物种濒危程度, 被公认为物种生物 多样性状况评估的权威性指标。《IUCN物种红色名 录濒危等级和标准》经历了不断商讨、修订至生效 的连续过程。目前, 最新的版本是2000年2月通过并 于2001年发布的3.1版。

该版本根据物种个体数量、物种地理分布、种 群破碎化程度以及种群下降趋势等标准数据将物 种保护级别分为 9 类。理论上, IUCN物种红色名录

收稿日期: 2017-04-28; 接受日期: 2017-07-10

基金项目: 环境保护部生物多样性保护专项——国高等植物红色名录

* 通讯作者 Author for correspondence. E-mail: yjia@ibcas.ac.cn
濒危等级和标准适用于地球上的所有动植物物种 的评估，所有生物分类单元也都可列入其中一个适 当的等级以便判断其生存现状。

然而，对于苔藓植物来说，由于其生物学特性 与栖息生境的特殊性, 以上的等级标准临界值范围 在实际评估中很难操作。一株乔木和一个苔藓植株 的生物量、繁殖扩散能力、所占空间大小的差距可 达万倍以上。因此, 为了使苔藓植物评估具有可操 作性, 有必要建立一些针对苔藓植物的方法和原则, 以期获得更加客观的评估结果。

Hallingbäck等(1996，1998)总结了1996年欧洲 (雷丁)苔藓生物学保护工作组会的讨论结果, 给广 
大苔藓学家提供了运用濒危等级处理苔藓植物的 方法指南, 其中包括特殊的案例以及处理建议。欧 洲学者依据此指南的原则、濒危等级和标准, 对一 些国家和地区的苔藓植物受威胁状况进行了评估。

2006年, 中国首次正式出版濒危苔藓植物红色 名录, 名录共包括82种(曹同等, 2006, Cao et al, 2006)。该名录是参照IUCN等级和标准, 再由全国 苔藓植物学专家通过讨论并作等级和标准的修订 之后确定的。

首批中国濒危苔藓植物名录出版已经过去了 10 年, 在此期间, 一系列的新分类群被发表, 一些物种 的名称和分类学地位发生了变化, 一些物种的分布 信息增加, 如中国新分布和省级新分布, 因此, 之前 被评估物种的濒危状态也随之发生了变化。为此, 本 文依据《IUCN物种红色名录濒危等级和标准》(IUCN, 2001), 并遵循Hallingbäck等(1998)提出的评估苔藓植 物方法指南中的原则, 对中国苔藓植物进行了重新评 估, 以更新并完善中国苔蘚植物红色名录。

\section{1 等级与标准}

\section{1 某些濒危等级的使用说明}

\subsection{1 灭绝 (EX)}

与维管植物相比, 苔藓植物几乎没有人工栽培, 因此, 对苔藓植物而言, 野外灭绝( $\mathrm{EW})$ 实际上就等 同于灭绝(EX)。

在欧洲一些地区，学者们根据不同年代植物区 系的对比, 得到灭绝的苔藓物种名单(Church et al, 2001)。然而, 这种方法仅适用于面积小、本底调查 彻底、研究历史悠久、数据积累详细清楚的地域。

确认一个物种的灭绝和野外灭绝需要在相当 长的时间范围内对该物种作定期的详细调查。就目 前我们所掌握的信息资料和研究程度, 要判断某 些中国苔藓植物是否灭绝是非常困难的。主要原因 如下:

(1)大量的微环境。中国幅员辽阔，除了地形地 貌、生境条件极其复杂之外, 可以生长苔藓植物的 微环境非常多样, 而我们又几乎没有针对性地对某 些物种的已知或可能的栖息地开展过系统性大规 模调查, 基础数据存在许多缺陷。

(2)植物体细小和混生现象。苔藓植物个体较其 他高等植物细小很多, 在野外要辨认到种很困难; 而且物种混杂生长的现象极为普遍, 即使在室内解
剖镜下观察，除非是由某类群专家仔细检视，否则 一些非常细小的物种经常被忽略而长期“闲置”在标 本馆中。

(3)配子体和孢子可以长期处于休眠状态。苔藓 植物不仅有很强的无性繁殖能力, 孢子也具有长期 休眠的能力。孢子或芽胞在不利于生长的环境中可 以长期休眠, 一旦环境适合, 就能很快萌发并形成 一定规模的居群。例如长台藓属(Oedipodium)的狍 子可以在 20 年之后依然保持活力(Chalaud, 1932); 梨蒴立碗藓(Physcomitrium pyriforme) 的孢子 55 年之 后仍能顺利地萌发(Doyle, 1970); 更有甚者, 南极 冰层下的一种离齿藓(Chorisodontium aciphyllum)可 在休眠1,500年后重新萌发(Roads et al, 2014)。

拟短月藓 (Brachymeniopsis gymnostoma) 曾记 录分布于云南丽江, 中国特有。本种模式标本采于 1916年，由于上次采集时间距今近100年，该地生 境变化很大。在《中国苔藓志》(第三卷)中有关该 种的描述、生境和分布点仍然是根据模式标本 (Brotherus, 1929)。2005、2006和2008年, 中美联合 考察队在其模式产地进行了 3 次有针对性的调查, 均没有发现该种。因此, 2010年该种被评估为灭绝 (EX)。2012-2013年, 深圳仙湖植物园的张力研究员 在西藏亚东县调查时, 重新发现并确认该种的存 在。他还推测, 在西藏亚东与云南丽江之间的地区 可能还有拟短月藓分布。因此本次评估将其濒危状 态更改为极危 $(\mathrm{CR})$ 。

总之, 灭绝等级应用于苔藓植物时需要相当慎 重。只有开展全方位的调查、监测工作, 才可能对 这一等级进行准确判断。

\subsection{2 近危(NT)}

把介于受威胁等级和无危等级之间的所有物 种列在近危(NT)等级中。本次评估主要依据是已采 集到的物种标本的数量和分布点, 以此推测种群状 况, 估计分布区面积, 由于野外调查还存在空白点, 只依靠现有标本状况推测和估计, 会低估物种的实 际数量和分布点数量, 所以近危种类所占比例可能 比实际情况略高。随着分类学研究的发展以及更多 地区的深入调查和标本采集量的增加, 某些种类的 分布面积和种群数量可能会有所扩大, 部分近危等 级中的种类有可能成为无危 $(\mathrm{LC})$ 等级。苔藓植物近 危等级的主要意义在于唤起人们的关注意识, 促进 对苔藓植物的研究、保护和监测。 


\subsection{3 数据缺乏(DD)}

一些学者在使用数据缺乏(DD)等级时, 会将其 细分为“评估资料数据缺乏”(DDD) 和“分类地位数 据存疑”(DDT)两个亚等级。在评估苔藓植物时, 我 们不再细分亚等级, 这主要是为了防止在评估过程 中过分考虑物种的分类修订问题而偏离评估方向。 在此需要强调的是, 物种的分类学地位是依据正式 出版的文献中合格发表的名称来确认。对中国苔藓 植物多样性而言, 物种本底调查和系统分类学研究 两方面都远远不足, 所以在整个评估中这个等级会 占有相当大的比例。

\section{2 濒危等级评估标准(A-E)的说明}

在实际情况中, 由于对濒危物种栖息地缺乏长 期(10年或更长时间)监测, 无法获得可靠的数据, 特别是对苔藓植物来说, 监测数据极少, 只有个别 的研究报道(汪岱华等, 2013), 很难获得长期有效的 数据, 只能通过推测和估计将来下降的比例。

苔藓植物的严格破碎化以种群孢子散布范围 之间的距离来衡量。以无性繁殖为主的类群, 种群 间距离大于 $50 \mathrm{~km}$, 被认为是严格破碎化。以有性繁 殖为主的类群, 严格破碎化的距离应在 100-1,000 $\mathrm{km}$ 之间(Hallingbäck et al, 1998)。

分布点物种的个体数目可用已鉴定标本采集 点的数量来计量, 按照严格破碎化的定义, 分布点 之间的距离应该超过 $50 \mathrm{~km}$ 。在实际的评估中通常 用一个县或一座山的位点来计算, 这些信息在标本 的采集记录中很容易获得。

如果物种数据处于 $\mathrm{B}$ 标准两个亚等级之间, 例 如，在物种既符合分布在 30 个 $10 \mathrm{~km} \times 10 \mathrm{~km}$ 的范围 内，又符合有 6 个分布点，那么这个物种应放在更 低的等级内(如：易危)。

烣类和种子植物用肉眼就很容易判断种类，并 直接估算成熟个体数量, 而即使非常有经验的苔藓 分类学家, 在野外也很难辨识大部分植株的具体种 类。对于野外无法识别的类群，可用采集并鉴定后 的标本来估算个体的数量。标本馆中的这些标本经 过专家鉴定, 不仅确定了物种名称, 还可以利用其 他的信息。成熟个体是指具有繁殖能力的个体的总 数。对苔藓植物这类集群生物, 一个无性系分株, 即一个既能独立生存 (有性或无性) 又能繁殖的最 小单元，应该被看作是一个“成熟个体”(IUCN, 2010）。在实际应用中通常用一小块或一从苔藓植
物来表示一个成熟个体。对于标本馆的标本而言, 根据野外工作经验，一份正常数量的标本可以代表 标本采集地点平均存在 50 个成熟个体。

中国苔藓植物由于缺少长期监测数据, 所以在 评估中, “E”标准实际上处于无法使用的状态。

\section{2 评估流程}

\section{1 评估名录}

原则上，评估范围包括所有合格发表并记录于 中国境内的苔藓植物。首要是通过对历史文献的搜 集整理，得出中国苔藓植物名录。事实上，任何地 区的物种名录都是动态变化的。分类单元的归并或 调整也是分类学研究成果的体现方式之一，而且随 着苔藓植物学家的广泛调查和深入研究, 很多新分 布记录和新类群也会随之增加。

因此, 红色名录应该是动态变化的, 需要定期 更新。为了保持名录的稳定性以便于评估，评估的 范围应该是在某个时间节点前正式发表的文献上 记录的物种。本次用于评估的名录发表时间节点是 2013年12月31日。

根据最新资料整理的名录，共计 151 科 604 属 3,221 种(包括种下等级)。

\section{2 重点物种信息调查}

苔藓植物按照其分布范围和数量，可首先区分 为重点评估物种和非重点评估物种。非重点物种是 指那些分布范围较广、野外成熟个体数量众多、种 群数量没有明显下降趋势的物种，可直接评估判定 为不受威胁的物种，列入“无危”(LC)等级。而重点 评估物种的情况较复杂, 需要先填写物种信息调查 表，按照调查表的数据进行进一步评估。

苔藓植物与其他高等植物的物种信息调查表 结构完全相同, 主要是针对评估标准 $\mathrm{A}-\mathrm{D}$ 的参数进 行填写。

对评估苔藓植物来说, 最重要的数据是: 种群 数量下降; 目前分布区大小和整个群体大小; 生长 点数量; 以及估计相关生境在过去 10 年内或 3 个世 代内的受损情况。

物种信息调查表的内容有一部分是红色名录 成文规则所要求的信息，它不仅对评估过程有重要 意义，也是形成评估结果的重要依据。在将来的评 估更新中，也是根据这些物种信息的变化状况对等 级和标准作相应的调整。填写物种信息调查表的人 
员以有野外工作经验的苔藓植物分类学家为主。

分类学家常会新发表某些地区的苔蘚植物名 录, 并提出其中某个物种符合以前所评估的红色名 录濒危等级。其实, 新的名录增加了该种的分布区 面积、种群数量、生长点数量等新的有效评估数据 信息, 其濒危等级也有可能会随之发生变化。我们 建议应该把关注点更多地放在“数据缺乏”(DD)等 级, 利用新数据进一步评估该等级的物种。

\section{3 篮选和评估}

根据苔藓植物重点物种信息调查表的数据, 按 照表1所示标准和等级进行评估, 确定濒危等级范 围中的“极危”(CR)、“濒危”(EN)和“易危”(VU)以及 其他等级(包括无危和数据缺乏), 将介于濒危等级 和无危等级之间的类群评估为“近危”(NT)等级。

通过下面的例子来说明评估的程序和方法:

(1)角齿藓Ceratodon purpureus (Hedw.) Brid.

\section{无危(LC)}

本种为世界广布种，在中国的分布范围较广， 黑龙江、内蒙古、吉林、辽宁、河北、陕西、江苏、 新疆、四川、云南、西藏等地区都有分布, 而且种群 下降趋势不明显, 所以可以直接判断为“无危”(LC)。

(2)尾尖小锦藓 Brotherella cuspidata Y. Jia et J.

\section{$\mathrm{M} . \mathrm{Xu}$ 数据缺乏(DD)}

本种为2006年发表的新种, 只在中国云南省发 现, 分布点较少, 成熟个体也少(Jia et al, 2006)。如 果按照评估标准, 有可能列入“濒危”等级, 但考虑 到该种发表年限较短, 有可能许多已采集的标本没 有及时被鉴定, 轻率给出濒危等级会造成误差, 所 以暂时将其列入“数据缺乏”(DD)。

(3)直叶曲尾蘚 Dicranum rectifolium Müll

\section{数据缺乏(DD)}

本种于1896年发表, 模式产地是陕西省, 为中 国特有种(Müller, 1896), 但其生境不详, 并且此后 再无报道和研究, 甚至在重要的专著《中国苔藓志》 (第一卷)(高谦，1994)中并未提及该种。因此，根据 现有资料首先我们无法确认该种的分类地位，也不 能判断其种群变化趋势和成熟个体数目, 更无法判 断其是否绝灭, 只能待今后的分类学研究和持续大 规模调查来获得更多的评估信息, 现列入 “数据缺 乏”(DD)等级。

(4)服角苔 Hattorioceros striatisporus (J. Haseg.)

\section{J. Haseg. 数据缺乏(DD)}

本种1994年以Phaeoceros striatisporus发表, 模式产地是印度(Hasegawa, 1994a), 在中国的西藏 有分布记录(Zhang et al，2011)。该种由于孢子小 $(<20 \mu \mathrm{m})$ 及表面具有小沟至条纹的纹饰而区别于 其他角苔类植物，随后Hasegawa (1994b) 将其作为一 个新属, 即Hattorioceros striatisporus。但最新的分 子系统学证据并不支持这个新属的成立 $(\mathrm{Li}$ et $\mathrm{al}$, 2011)。

彭涛博士在研究中国角苔植物的分类修订和 分子系统发育时，发现云南、贵州有该种的分布， 并观察到两地的标本与在国外(斐济、印度)发现的 该种标本类似：一是其狍蒴中存在两种孢子形态， 二是所有Phaeoceros striatisporus标本都与林氏黄 角苔(Phaeoceros carolinianus)混生在一起，据此， 他对Phaeoceros striatisporus是否成立产生疑问。因 为Eckstein等(2007)发现一些苔类和藓类有被真菌 感染的现象, 并发表了一个与Phaeoceros striatisporus形态非常相似的未知真菌孢子(Eckstein \& Döbbeler, 2007), 彭涛博士推测, Phaeoceros striatisporus很可能是被真菌感染了孢蒴的林氏黄 角苔, 但是这一推测还需要进一步的研究获得证 据。毫无疑问，服角苔在分类学上仍然存在问题， 所以我们将其列入“数据缺乏”(DD)。

(5)圆蒴烟杆藓 Buxbaumia symmetrica Chen et Lee 极危(CR)

本种为我国秦岭地区特有, 2004年《中国首批 濒危苔藓植物红色名录简报》中将本种列入 “极 危”(CR)。这次评估中根据物种信息调查表资料, 本 种适用以下标准:

$\mathrm{A}$ : 由于原产地存在大规模开发, 引起生境质 量衰退, 而且该种植物对于环境变化的敏感程度极 高, 据此推测种群 10 年或 3 个世代下降的范围 $\geq$ $80 \%$ ，列入“极危”(CR);

$\mathrm{B}$ : 分布面积小且衰退, 面积小于 $100 \mathrm{~km}^{2}$, 分 布点只有 1 个; 列入“极危”(CR);

$\mathrm{C}$ : 种群规模小, 亚种群数不详, 该标准不适 合使用;

D: 局限分布, 且成熟个体数小于 50 个, 列入 “极危”(CR)。

综上，本种列入“极危”(CR) 等级 $[\mathrm{A} 3 \mathrm{~cd}$; $\mathrm{B} 1 \mathrm{ab}$ (iii); D]。

(6)庐山耳叶苔 Frullania lushanensis S. Hatt. et 


\section{Lin 濒危(EN)}

本种为中国特有, 在江西和湖南有记录 (Hattori et al, 1985)。根据物种调查信息表资料:

A：种群变化趋势不详，该标准不适合使用;

B: 分布面积少于 $5,000 \mathrm{~km}^{2}$, 分布点 2 个, 且栖 息地质量下降，列入“濒危”(EN);

$\mathrm{C}$ : 种群小, 亚种群数不详, 该标准不适合 使用;

D：推测成熟个体数小于 1,000 个, 列入 “易 危”(VU)。

综上, 本种评估列入较高等级, 为“濒危”(EN) [B1ab(iii)]。

(7)新线苔 Neotrichocolea bissetii (Mitt.) S. Hatt.

\section{易危(VU)}

本种分布于我国安徽、贵州、云南、福建和浙 江, 日本也有记录(Hattori, 1947; 陈邦杰等, 1958; 陈邦杰和吴鹏程, 1965; Zhu et al, 1998; 高谦和曹同, 2000; Liu et al, 2008; Zhang et al, 2011)。根据物种调 查信息表资料:

A: 在整个分布区范围内种群变化不详, 但是 在黄山已被证实种群数量急剧减少或消失(师雪芹 等, 2009), 推测该种群在 10 年内下降 $\geqslant 30 \%$, 列入 “易危”(VU);

B: 分布面积大于 $20,000 \mathrm{~km}^{2}$, 该标准不适合 使用。

$\mathrm{C}$ : 种群小, 在衰退, 亚种群成熟个体数持续 下降, 10 年内 $>10 \%$ ，列入“易危”(VU);

$\mathrm{D}$ : 推测成熟个体数小于 1,000 个，列入 “易 危”(VU)。

综上原因，本种评估列入 “易危”(VU) 等级 [A3ac; C1; D1]。

某些种类生境状况保持稳定, 种群没有明显下 降趋势, 而且分布面积大于 $20,000 \mathrm{~km}^{2}$, 但是目前 所知的分布点个数不超过 10 个, 成熟个体数也不超 过2,500, 目前一般放到近危(NT)等级。随着以后调 查的深入，该等级物种的濒危程度可能会发生变化， 如: 暖地网藓(Syrrhopodon tjibodensis)。

\section{4 专家审核}

完成初评的名录反馈给国内部分苔藓学家进 行审核, 根据他们的经验和建议对个别物种的濒危 等级进行了调整。如厚边藓(Sciaromiopsis sinensis), 曾经被评为极危(CR) (Cao et al, 2006b), 但根据吴
玉环最新填写的调查表, 在重庆(南川县)、四川(木 里县, 盐边县)、云南(槛海县)、西藏(墨脱县)都发现 该种分布, 其生存环境稳定, 种群数量也无明显降 低趋势，可列入无危(LC)。

\section{3 评估结果}

对 3,221 个中国苔藓植物分类单元进行评估的 结果(贾渝, 2017)如下: 极危(CR) 16种; 濒危(EN) 58种; 易危(VU) 112种; 近危(NT) 214种; 无危(LC) 1,900种; 数据缺乏(DD) 921种(图1)。极危、濒危和 易危等级的受胁苔藓植物合计 186 种, 占中国苔藓 植物种数的 $5.77 \%$ 。

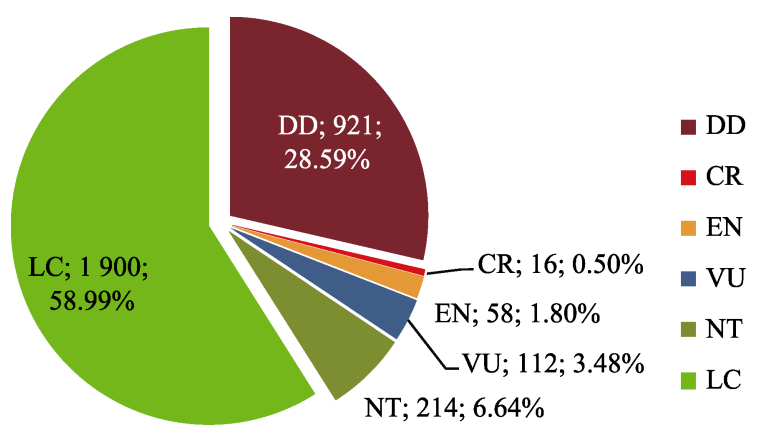

图1 红色名录中各等级占中国苔藓植物种数的比例。DD: 数据缺乏; CR: 极危; EN: 濒危; VU: 易危; NT: 近危; LC: 无危。

Fig. 1 Proportion of each Red List category of Chinese bryophytes. DD, Data Deficient; CR, Critically Endangered; EN, Endangered; VU, Vulnerable; NT, Near Threatened; LC, Least Concern.

濒危等级所占比例偏少的原因是由于一些潜 在受威胁的物种, 因现有评估资料不足而被列入数 据缺乏(DD)等级。需要强调的是, 被评为数据缺乏 (DD)等级并不说明该物种不濒危或不需要关注, 恰 恰相反, 有一些具有重要分类价值或潜在濒危的重 点物种会被归入这个等级中, 只是现有研究水平和 数据还无法准确评估、判断其濒危状况。分类学家 最新发表的名录里, 就可能包括被评为数据缺乏 (DD)等级的种类, 完全可以根据新补充的数据来更 新其评估等级。如果将其中大部分视为潜在受威胁 等级, 那么受威胁等级的数量会超过中国苔藓植物 总数的 $20 \%$ 以上。

\section{4 讨论}

苔藓植物鉴定要依靠显微镜在室内进行, 野外 
很难鉴定到种, 更谈不上统计具体种类的成熟个体 数量, 评估时只能充分利用文献和鉴定过的标本信 息。文献中可利用的数据是物种名称、分布范围及 所引证标本数量。标本采集信息除了以上可用数据, 还能以标本份数估算成熟个体数量, 因调查苔藓植 物时采集标本是随机进行, 若同一采集地的同一种 类标本份数较多, 说明当地该物种成熟个体数目多, 种群数量也大; 还可以根据标本采集信息中小地名 的生境变化推测种群数量变化趋势。

将 10 年内发表的新类群或新分布物种列入数 据缺乏(DD)等级, 主要考虑到新发表类群一般引证 标本极少, 无法据此判断其种群数量或变化趋势。 随着对该种进行更深入的研究, 还可能出现两种情 况: 一是其在分类学修订中被归并; 二是分类学家 根据新物种发表文献, 在以往或最新采集的标本中 确认新类群, 混杂在同一份标本中个体很小的植株 在鉴定过程中容易被忽略, 这些被忽略的植株可能 就包括新发表的类群。以上情况都会改变物种濒危 等级, 为了保持名录濒危等级的相对稳定性, 暂时 放入数据缺乏(DD) 等级较为合理。随着苔藓分类学 家的持续性工作, 数据缺乏(DD) 等级的种将会被陆 续评估, 并给予适当的评级。

在对名录进行评估审核时, 如对某一物种的名 称、分布范围和种群数量等信息存疑, 原则上以正 式出版的文献或专家鉴定的标本为依据, 必要时可 请专家提供所鉴定标本的详细信息来验证, 但是最 终的结果应该由深入的分类学研究来确定。例如, 原来一直被认为是在新西兰受到威胁的珍稀物种 Chorisodontium aciphyllum (Hook. f. \& Wilson) Broth., 经过研究是基于错误鉴定的结果, 而实际 应该是分布相对广泛的Holomitrium trichopodum (Mitt.) Klazenga (Fife et al, 2010)。

本次评估主要是遵循IUCN物种红色名录濒危 等级和标准的原则, 考虑到中国实际情况和评估的 可操作性而进行, 其评估结果的客观性取决于分类 学家填写物种调查信息表资料的全面性和准确性。 在实际评估过程中, 相当一部分物种缺乏详细、准 确的资料, 无法给出恰当的濒危等级。为了获得符 合实际的客观数据和评价, 要培养更多的苔藓分类 学家, 不仅要对中国苔藓植物分类学进行深入研究, 而且要开展大规模的区域调查和对特定物种的持 续性监测, 这将是未来中国苔藓植物保护学的工
作重点。

致谢: 本文得到了蔡蕾博士和覃海宁研究员支持; 吴鹏程研究员、高谦研究员、曹同教授、白学良教 授、王幼芳教授、赵建成教授、张力研究员、吴玉 环教授、李薇博士协助审核部分名录并提出修改建 议, 朱瑞良教授对本研究提出了宝贵意见。在此一 并表示感谢!

\section{参考文献}

Brotherus VF (1929) Botanische Ergebnisse der Expedition der Akademie der Wissenschaften in Wien nach Sudwest-China In Symbolae Sinicae. 1914/1918. IV. Musci. (ed. Handel-Mazzetti H), pp.1-147. Julius Springer, Berlin.

Cao T, Zhu RL, Guo SL, Zuo BR, Yu J (2006) A brief report of the first red list of endangered bryophytes in China. Bulletin of Botanical Research, 26, 756-762. (in Chinese with English abstract) [曹同, 朱瑞良, 郭水良, 左本荣, 于晶 (2006) 中国首批濒危苔藓植物红色名录简报. 植物研究, 26, 756-762.]

Cao T, Zhu RL, Tan BC, Guo SL, Gao C, Wu PC, Li XJ (2006) A report of the first national red list of Chinese endangered bryophytes. Journal of the Hattori Botanical Laboratory, 99, 275-295.

Chalaud G (1932) Germination des spores et phase protonemique. In: Manual of Bryology Chapt. IV (ed. Verdoorn F), pp. 89-108. Martinus Nijhoff, The Hague.

Chen PC (1958) Preliminary report of the ecological and geographical study of Chinese mossflora. Acta Phytotaxonomica Sinica, 7, 271-293. (in Chinese) [陈邦杰等(1958) 中国苔藓植物生态群落和地理分布的初步报告. 植物分 类学报, 7, 271-293.]

Chen PC, Wu PC (1965) The preliminary study of the bryophytes of Mt. Hwangshan. In: Observations ad Florulam Hwangshanicam (eds Chen PC, Wu PC, Chiu PH, Hsu PS, Chow CL), pp. 1-59. Shanghai Science and Technology Press, Shanghai. (in Chinese) [陈邦杰, 吴鹏程 (1965) 黄山苔藓植物的初步研究. 见: 《黄山植物的研 究》(陈邦杰, 吴鹏程, 雸佩喜, 徐炳声, 周纪纶著), 1-59 页. 上海科学技术出版社, 上海.]

Church JM, Hodgetts NG, Preston CD, Stewart NF (2001) British Red Data Books: Mosses and Liverworts. Joint Nature Conservation Committee, Peterborough, UK.

Doyle WT (1970) The Biology of Higher Cryptogams. Macmillan, New York, and Collier Macmillan, London.

Eckstein J, Döbbeler P (2007) Fungal spores within sporophytes of Gymnostomum viridulum. Journal of Bryology, 29, 169-173.

Fife AJ, Glenny D, Beever JE, Braggins JE, Brownsey PJ, Renner MAM, Hitchmough R (2010) New Zealand's 
threatened bryophytes: conservation efforts. Phytotaxa, 9, 275-278

Gao C (ed.) (1994) Flora Bryophytorum Sinicorum, Vol. 1. Science Press, Beijing. (in Chinese) [高谦 (主编) (1994) 《中国苔藓志》第一卷. 科学出版社, 北京.]

Gao C, Cao T (ed.) (2000) Flora Yunnanica, Tomus 17 (Bryophyta: Hepaticae, Anthocerotae). Science Press, Beijing. (in Chinese) [高谦, 曹同 (主编) (2000) 《云南植 物志》17卷(苔藓植物: 苔纲、角苔纲) 科学出版社, 北京.] Hallingbäck T, Hodgetts N, Raeymaekers G, Schumacker R, Sérgio, C, Söderström L, Stewart N, Vána (1998) Guidelines for application of the revised IUCN threat categories to bryophytes. Lindbergia, 23, 6-12.

Hallingbäck T, Hodgetts NG, Urmi E (1996) How to use the new IUCN Red List categories on bryophytes. Guidelines proposed by the IUCN SSC Bryophyte Specialist Group. Anales Del Instituto De Biología Serie Botánica, 67, 147.

Hasegawa J (1994a) A remarkable new species of Phaeoceros (Anthocerotae) with canaliculate-striate spore surfaces. Journal of the Hattori Botanical Laboratory, 75, 267-273.

Hasegawa J (1994b) New classification of Anthocerotae. Journal of the Hattori Botanical Laboratory, 76, 21-34.

Hattori S (1947) Contributio ad Floram Hepaticarum Yakusimensem, II. Journal of the Hattori Botanical Laboratory, 2, 1-26.

Hattori S, Lin PJ (1985) A preliminary study of Chinese Frullania flora. Journal of the Hattori Botanical Laboratory, $59,123-169$.

IUCN (2001) IUCN Red List Categories and Criteria. Version 3.1.IUCN Species Survival Commission, Gland, Switzerland \& Cambridge, UK. [ii +30 pp.]

IUCN (2010) Guidelines for Using the IUCN Red List Categories and Criteria Version 8.0 (March 2010). http://intranet.iucn.org/webfiles/doc/SSC/RedList/RedListG uidelines.pdf.

Jia Y (2017) Bryophytes In: Species Catalogue of China, Volume 1, Plants. A Provisional Checklist (Book one) (eds Wang LS, Jia Y, Zhang XC, Qin HN), Science Press, Beijing. (in Chinese) (in press) [贾渝 (2017) 苔藓植物. (见: 中国生物物种名录 第一卷 植物总名录(上册). (王 利松, 贾渝, 张宪春, 覃海宁主编). 科学出版社. 北京] (印刷中)
Jia Y, Xu JM (2006) A new species and a new record of Brotherella (Musci, Sematophyllaceae) from China, with a key to the Chinese species of Brotherella. Bryologist, 109, 579-585.

Li JY, Zhang L, Zhou LP (2011) Phylogenetic position of the genus Hattorioceros (Anthoceratophyta). Taxon, 11, 1-4

Liu Y, Jia Y, Wang W, Chen CZ, Davis EC, Qiu YL (2008) Phylogenetic relationships of two endemic genera from East Asia: Trichocoleopsis and Neotrichocolea (Hepaticae). Annual of Missouri Botanical Garden, 95, 463-474.

Müller C (1896-98) Bryologia Provinciae Schen-si Sinensis. I. Nuovo Giornale Botanico Italiano, n.s., 3, 89-129.

Roads E, Longton RE, Convey P (2014) Millennial timescale regeneration in a moss from Antarctica. Current Biology, 24, 222-223.

Shi XQ, Wu KM, Zhang XP (2009) Studies on liverwort flora in Huangshan Mountain. Journal of Wuhan Botanical Research, 27, 368-273. (in Chinese with English abstract) [师雪芹，吴开明，张小平 (2009) 黄山苔类植物区系研 究. 武汉植物学研究, 27, 368-372. ]

Wang DH, Wang YF, Zuo Q, Li M, Wei QQ, Li XQ, Zhao MS (2013) Comparison of bryophyte diversity in West Tianmu Mountain from 1977 to 2011. Biodiversity Science, 21, 170-176. (in Chinese with English abstract) [汪岱华, 王幼 芳，左勤，李敏，魏倩倩，李晓芹，赵明水 (2013) 浙江 西天目山30年来苔藓物种多样性变化. 生物多样性, 21 , 170-176.]

Zhang L, Zhou LP, Li JY (2011) The genus Hattorioceros (Notothyladaceae) new to China. The Bryologist, 114, 190193.

Zhang XQ, Zhu RL, Huang ZS, ChenYT, Chen WW (2011) Liverworts and Hornworts of Fujian, China: An Updated Checklist and Bryofloristic Accounts. Plant Diversity, 33, 101-122. (in Chinese with English abstract) [张晓青, 朱瑞 良，黄志森，陈允泰，陈文伟 (2011) 福建苔类和角苔类 最新名录与区系分析. 植物分类与资源学报, 33 , 101-122.]

Zhu RL, So ML, Ye LX (1998) A synopsis of the Hepaticae flora of Zhejiang, China. Journal of the Hattori Botanical Laboratory, 84, 159-174.

(责任编委: 朱瑞良 责任编辑: 时意专)

\section{附录 Supplementary Material}

附录1 中国苔藓红色名录参考文献

Appendix 1 References of the Red List of Chinese bryophytes http://www.biodiversity-science.net/fileup/PDF/2016205-1.pdf 
何强, 贾渝. 中国苔蘚植物濒危等级的评估原则和评估结果. 生物多样性, 2015, 25 (7): 774-780.

http://www.biodiversity-science.net/CN/10.17520/biods.2016205

附录1 中国苔蘚红色名录参考文献

Appendix 1 References of the Red List of Chinese bryophytes

Bai XL (2002) Crossidium aberrans Holz. \& Bartr. (Musci, Pottiaceae), a new record from Asia. Hikobia, 13, $637-640$.

Cao T, Guo SL (2001) Ptychomitrium yulongshanum Cao \& Guo, a new moss species from China. The Bryologist, 104, 303-304.

Chao HC (1943) Studies on the Hepaticae of Fukien. Collected Papers, National University of Amoy, 1, 101-144.

Chao RF, Lin SH (1991) A taxonomic study of Frullaniaceae from Taiwan (I). Yushania, 8, 7-19.

Chen LZ (1993) China's Biodiversity: Status and Protection Countermeasures. Science Press, Beijing. (in Chinese) [陈灵芝 (1993) 中国的生物多样性：现状及其保护对策. 科学出版社，北京.]

Chiang TY (1998) The mosses of Taiwan: their conservation status. In: Rare, Threatened, and Endangered Floras of Asia and the Pacific Rim (eds Peng CI, Lowry PP), pp.89-110. Institute of Botany, Academia Sinica, Taipei.

Furuki T, Higuchi M (1997) Oil bodies and oil droplets of some hepatics from Sichuan, China. Bulletin of the National Science Museum, 23, 81-102.

Gao C (1977) Flora Muscorum Chinae Boreali-orientalis. Sciense Press, Beijing. (in Chinese) [高谦 (1977) 东北 藓类植物志. 科学出版社, 北京]

Gao C, Zhang GC (1978) Species novae Ricciacearum Chinae boreali-orientalis. Acta Phytotaxonomica Sinica, 16, 113-118. (in Chinese) [高谦, 张光初 (1978) 中国东北地区钱苔科新植物. 植物分类学报, 16, 113-118.]

Guo W, Zhang MX (1999) The taxonomic study of Anthocerotaceae in Shaanxi, Northwest China. Chenia, 6, 21-34.

Hallingbäck T (1998) The new IUCN categories tested on Swedish bryophytes. Lindbergia, 23, 13-27.

Hallingbäck T, Hodgetts N (2000) Status Survey and Conservation Action Plan for Bryophytes Mosses, Liverworts and Hornworts. Information Press, Oxford.

Hallingbäck T, Hodgetts N, Urmi E (1995) How to apply the new IUCN Red List categories to bryophytes. Species, 24, 37-41.

Han GY, Song PL, He XG, Zhao ZT (2010) New discovery and correction the distribution of Chinese endangered endemic liverwort Ascidiotable pharophylla C. Massal. Seed, 29(3), 70-71. (in Chinese with English abstract) [韩国营, 宋培浪, 何先贵, 赵遵田 (2010) 中国濒危苔藓植物耳芏苔分布的新发现及错误更正. 种子, 29(3), 70-71.]

Hattori S (1967) Studies of the Asiatic species of the genus Porella (Hepaticae). I. Some new or little known Asiatic species of Porella. Journal of the Hattori Botanical Laboratory, 30, 129-151.

Hattori S (1982) A small collection of Frullania from Yunnan and Sichuan. Bulletin of the National Science Museum, Tokyo, Series B, 8(3), 93-100.

Hattori S, Zhang MX (1985) Porellaceae of Shensi Province, China. Journal of Japanese Botany, 60, 321-326.

Herzog T, Noguchi A (1955) Beitrag zur Kenntnis der Bryophytenflora von Formosa und der benachbarten Inseln Botel Tobago und Kwashyoto. Journal of the Hattori Botanical Laboratory, 14, 29-70.

Higuchi M (1998) A new species of Apotreubia (Treubiaceae, Hepaticae) from China. Cryptogamie Bryologie, 19 , 320-322.

Higuchi M, Wang LS, Long DG (2000) Haplomitrium hookeri (Sm.) Nees new to China and Apotreubia yunnanensis Higuchi new to Sichuan. Bryological Research, 7, 309-313.

$\mathrm{Hu}$ XY, Wu PC (1991) Study on the mossflora of Mt. Jinfu, Sichuan Province. Acta Phytotaxonomica Sinica, 29, 315-334. (in Chinese with English abstract) [胡晓云, 吴鹏程 (1991) 四川金佛山藓类植物区系的研究. 植 物分类学报, 29, 315-334.]

Jia Y, He S (2013) Species Catalogue of China, Vol.1. Plant, Bryophytes. Science Press, Beijing. (in Chinese) [贾 渝，何思 (2013) 中国生物物种名录(第一卷): 植物, 苔藓植物. 科学出版社, 北京.]

Jia Y, Wu PC (1998) Conservation of bryophytes in China. Chenia, 5, 123-128.

Kučera J, Váňa J (2003) Check- and Red List of bryophytes of the Czech Republic. Preslia, Praha, 75, 193-222.

Li M, Zhao JC (2002) The bryophytes in Mt. Xiaowutai of Hebei Province, North China. Chenia, 7, 111-124.

Li ZH, Cao T, Yu J, Sun SQ (2011) New records of mosses to Sichuan Province, China. Guihaia, 31, 314-317. 
Lin PJ, Koponen T, Piippo S (1992) Bryophyte flora of Jianfengling Mts., Hainan Island, China. Bryobrotherea, 1, 195-214.

Liu ZL, Li DK, Gao CH (1989) Mosses and liverworts. In: Cryptogamic Flora of the Yangtze Delta and Adjacent Regions (ed. Xu BS), pp. 267-413. Shanghai Scientific and Technical Publishers, Shanghai. (in Chinese) [刘仲 苓等 (1989) 苔藓植物. 见: 长江三角洲及邻近地区狍子植物志(徐炳声主编), 267-413页. 上海科学技术 出版社, 上海.]

Long DG (2006) Notes on Himalayan Hepaticae 3: New records and extensions of range for some Himalayan and Chinese Marchantiales. Cryptogamie Bryologie, 27, 119-129.

Luo JX, Zhang YM, Chen XS (1991) A prelimiary study bryophytes in Laoshan. Journal of Shandong Agricultural University (Natural Science Edition), 22(1), 63-70. (in Chinese with English abstract) [罗键馨, 张艳敏, 陈学 森 (1991) 崂山苔藓植物初报. 山东农业大学学报, 22(1), 63-70.]

Mao LH, Zhang L (2011) Mosses of Lancangjiang River valley (Yunlong-Deqin section), Yunnan, China. Journal of Fairylake Botanical Garden, 10, 11-20.

Mitten W (1859) Musci indiae orientalis; an enumeration of the mosses of the east indies. Journal of the Proceedings of the Linnean Society of London. Botany, 3(Suppl.1), 1-96.

Mitten W (1864) On some species of musci and hepaticae, additional to the floras of Japan and the coast of China. Botanical Journal of the Linnean Society, 8(31), 148-158.

Natcheva R, Ganeva A, Spiridonov G (2006) Red List of the bryophytes in Bulgaria. Phytologia Balcanica, 12 , $55-62$.

Peng CL, Enroth J, Koponen T, Piippo S (2000) The bryophytes of Hubei Province, China: an annotated checklist. Hikobia, 13, 195-211.

Peng T, Zhang CH (2007) New records of the bryophytes in Guizhou Province. Journal of Guizhou Normal University (Natural Science Edition), 25(2), 20-24. (in Chinese with English abstract) [彭涛, 张朝辉 (2007) 贵州省苔藓植物新记录. 贵州师范大学学报, 25(2), 20-24. ]

Piippo S (1990) Annotated catalogue of Chinese Hepaticae and Anthocerotae. Journal of the Hattori Botanical Laboratory, 68, 1-192.

Piippo S (2010) Bryophyte flora of Hunan Province, China. 15. Genera Asterella, Fossombronia, Isotachis, Jubula and Metzgeria (Aytoniaceae, Fossombroniaceae, Balantiopsaceae, Jubulaceae and Metzgeriaceae). Acta Bryolichenol. Asiatica, 3, 145-150.

Potemkin A (2002) Phylogenetic system and classification of the family Scapaniaceae Mig. emend. Potemkin (Hepaticae). Annales Botanici Fennici, 39, 309-334.

Rao PC (2000) Taxonomic studies on Cryphaea (Cryphaeceae, Bryopsida) 2. Revision of Asian species. Annales Botanici Fennici, 37, 45-56.

Redfearn P, Tan BC, He S (1996) A newly updated and annotated checklist of Chinese mosses. Journal of the Hattori Botanical Laboratory, 79, 163-357.

Sabovljevic M, Cvetic T, Stevanovic V (2004) Bryophyte Red List of Serbia and Montenegro. Biodiversity and Conservation, 13, 1781-1790.

Tan BC, Jia Y (1997) Mosses of Qinghai-Tibetan Plateau, China. Journal of the Hattori Botanical Laboratory, 82, 305-320.

Tan BC, Jia Y (1999) A preliminary revision of Chinese Sematophyllaceae. Journal of the Hattori Botanical Laboratory, 86, 1-70.

Tan BC, Li ZH, Lin PJ (1987) Preliminary list of mosses reported from Hainan Island, China. Yushania, 4(4), 5-8.

Tan BC, Lin PJ (1995) Three new species species of mosses from China. Tropical Bryology, 10, 55-63.

Tan BC, Zhao JC, Hu RL (1995) An updated checklist of the mosses of Xinjiang, China. Arctoa, 4, 1-14.

Wu PC, Li DK, Gao CH (1981) New records of bryophytes in Mt. Wuyi, China. I. Journal of Wuyi Science, 1, 16-18. (in Chinese with English abstract) [吴鹏程, 李登科, 高彩华 (1981) 武夷苔藓新分布(一). 武夷科 学, 1, 16-18.]

Wu YH, Gao C (2006) Notes on Chinese Cyathodium Kunze. Bulletin of Botanical Research, 26, 522-526. (in Chinese with English abstract) [吴玉环，高谦 (2006) 中国光苔属资料. 植物研究, 26, 522-526.]

Wu YH, Gao C (2008) Chiloscyphus sikkimensis (Geocalycaceae, Hepaticae) New to mindland of China. Bulletin of Botanical Research, 28, 520-521. (in Chinese with English abstract) [吴玉环，高谦 (2008) 地萼苔科锡金 裂萼苔(Chiloscyphus sikkimensis)在中国大陆的新分布. 植物研究, 28, 520-521.]

Yang BY (1963) Further studies on Taiwan Hepaticae the genus Thysananthus. Taiwania, 9, 23-31.

Yang JD (2009) Liverworts and Hornworts of Taiwan. I. Lejeuneaceae. Taiwan Endemic Species Research Institute, Taichung. pp. 1-62. 
Zeng SY (1990) Taxonomy of Ditrichum from Yunnan. Acta Botanica Yunnanica, 12, 293-300. (in Chinese with English abstract) [曾淑英 (1990) 云南牛毛藓属的分类. 云南植物研究, 12, 293-300.]

Zhu RL, Gradstein SR (2005) Monograph of the Lopholejeunea (Spruce) Schiffn. (Lejeuneaceae, Hepaticae) in Asia. Michigan: The American Society of Plant Taxonomists. ISBN: 0-912861-74-6. (Systematic Botany Monographs 74.)

Zhu RL, Hu RL, Ma YJ (1994) Some comments on rare and endangered liverworts in mainland China. Arctoa, 3, 7-12.

Zhu RL, So ML (2001a) Epiphyllous liverworts of China. Nova Hedwigia Beiheft, 121, 1-418. J. Cramer. Berlin.

Zhu RL, So ML (2003) Liverworts and hornworts of Shangsi County of Guangxi (Kwangsi), with an updated checklist of the hepatic flora of Guangxi Province of China. Cryptogamie Bryologie, 24, 319-334.

Zhu RL, So ML, Grolle R (2001b) Cheilolejeunea gaoi (Hepaticae, Lejeuneaceae), a new species from Guangxi, China. Bryologist, 103, 499-502.

Zuo Q, Liu Q, Wang YF (2010) Study on moss flora of Maoershan Nature Reserve, Guangxi. Guihaia, 30, 850-858. (in Chinese with English abstract) [左勤, 刘倩, 王幼芳 (2010) 广西猫儿山自然保护区藓类植物区 系研究. 广西植物, 30, 850-858. ] 